\title{
Johannine research in Africa, part 1: An anlytical survey
}

\author{
Author: \\ Jan G. van der Watt ${ }^{1,2}$ \\ Affiliations: \\ ${ }^{1}$ source Texts of Judaism \\ and Christianity, Radboud \\ University Nijmegen, \\ Nijmegen, the Netherlands \\ ${ }^{2}$ Department of New \\ Testament, University of the \\ Free State, South Africa

\section{Correspondence to:} \\ Jan van der Watt \\ Email: \\ j.vanderwatt@ftr.ru.nl

\section{Postal address:} \\ Paterserf 07, Molenhoek \\ 6584 GA, the Netherlands \\ Dates: \\ Received: 15 Jan. 2015 \\ Accepted: 22 May 2015 \\ Published: 24 July 2015 \\ How to cite this article: \\ Van der Watt, J.G., 2015 \\ 'Johannine research in Africa, \\ part 1: An anlytical survey', In \\ die Skriflig 49(2), Art. \#1928, \\ 14 pages. $h t t p: / / d x . d o i$. \\ org/10.4102/ids.v49i2.1928

\section{Copyright:} \\ C 2015. The Authors. \\ Licensee: AOSIS \\ OpenJournals. This work is \\ licensed under the Creative \\ Commons Attribution \\ License.
}

\section{Read online:}

This article is the first of two parts that contribute to the history of African biblical research. Africa's theological 'awakening', following the colonial period, includes the discipline of New Testament studies. In this article the contributions of theologians working in Africa on the field of Johannine studies are surveyed and evaluated. In certain areas theologians from Africa performed very well, whilst other areas should receive more attention.

Johannese navorsing in Afrika, deel 1: 'n Analitiese oorsig. Hierdie artikel is die eerste van twee, wat saam ' $n$ bydrae tot die geskiedenis van Bybelnavorsing in Afrika wil lewer. Afrika se teologiese bewuswording wat op die koloniale periode volg, sluit die dissipline van NuweTestamentiese navorsing in. In hierdie artikel word die bydrae van teoloë wat in Afrika werk, ondersoek en ge-evalueer. In sekere areas het die teoloë uit Afrika besonder goed gevaar, maar ander areas behoort meer aandag te geniet.

\section{Introduction}

Reflecting on Johannine research (from here, John) in Africa is a challenging but rewarding endeavour for several reasons. It is, for instance a question what should be understood under the theme 'Johannine research in Africa'? ${ }^{1}$ The question what should be regarded as 'Africa' is also relevant, since Africa is divided into different areas with artificial borders resulting from its colonial history. ${ }^{2}$ Due to the colonial history there are even questions like who a true African is, especially when it comes to people from European descent.

There are several valid ways of approaching the question of John in Africa which implies that definite choices should be made of what and who are going to be discussed or not. Here the emphasis will be on accessible research ${ }^{3}$ by people (irrespective of who they are) ${ }^{4}$ who reside or resided in sub-Saharan Africa. ${ }^{5}$

Finding 'African Johannine material' is also no mean task ${ }^{6}$ since we lack good and reliable databases on Johannine research in Africa, with the exception of the bibliography of LeMarquand (2000) on New Testament publications in Africa. ${ }^{7}$ No real database on Johannine research in Africa exists - this lacuna is addressed in Part 2, namely 'Johannine research in Africa, part 2:

1.Is it research on Johannine material somehow related to Africa (irrespective where it is done)? Or is it research of people who live in Africa who publish on Johannine themes (irrespective of the theme or nature of the research)? If the research is focused purely on theological issues current in the international predominantly western theological debate, should that be regarded as African research even though it might be done by a person living in Africa? Or should the research reflect an African ethos?

2.The terms Africa and African are not easy to define. It may refer to the geographical continent, or to sub-Saharan Africa, since it is felt that the top part of the continent differs from the sub-Saharan part in many ways, et cetera. Since the Roman times these Mediterranean countries had their own history.

3.Masters- and doctoral research will not be considered in detail, except if it is published in a book. Only one or two master and doctora publications will be reflected in the bibliography, just to give some taste of what is being done on this level.

4.There are many views and definitions of who an African is. I do not want to go into this debate, but use the criterion of residency as guiding principle. This means that if a person researches at an African University, that person qualifies as African under this definition since such a person drank from the well of African scholarship. I did use one filter and that is where a person comes from, for instance South Korea - and there are and were many who pursue(d) degrees South African Universities - and it seems that the researcher was purely interested in getting a degree and not really engaging with Africa - I did not mention that research.

5.The emphasis is going to fall on sub-Saharan Africa, because little is done in this field in the Mediterranean areas of Africa for several reasons that need not be discussed here. Due to the fact that it is difficult to define an 'African ethos', sharing this ethos is not going to be a primary focus.

6.West (2000c:5) also identified this problem. African research is spread very thinly in Johannine databases, which makes it difficult to identify.

7.This is the most extensive bibliography on New Testament research in Africa. It has its limitations. It only deals with publications up to 2000. (Bishop LeMarquand was so kind to make available to me his unpublished data of publications after that date). The bibliography also reflect very little of the research done in the Southern part of Africa, which is and was of course the powerhouse of New Testament scholarship in Africa over many years, although scholarship in countries like Nigeria, Kenya and Ghana made and are making significant progress in their development of New Testament research. 
An annotated bibliography ${ }^{\prime 8}$ I am convinced that Africa is in need of a comprehensive, reliable and easily accessible databank for the research done on the continent. This is if we would like to stay informed about what happens all over the continent and build on that, not restricting ourselves to our own (geographically) closed circles of influence. This is the reason for the extensive bibliography at the end of this article. Hopefully, this would fill some voids.

I mainly restricted myself to publications that are clearly about John which is consciously reflected in the title of the research (see the bibliography). ${ }^{9}$ Obviously there are many references in articles that do not specifically deal with John, but do have references to Johannine material. They are not discussed here, since this article specifically focuses on John.

Firstly, some aspects that John shares with New Testament research in general, that is dealing with hermeneutics and approaches or certain key areas of research will receive attention. Then attention will shift to specifically Johannine research done in the Southern part of Africa, gradually moving to Africa as a whole, analysing the research in different areas and on different topics.

\section{Is Africa a continent for (Johannine) research?}

In surveying Johannine research in Africa there are special issues to consider. These issues have roots in New Testament research in general and as such also have direct bearing on John. It must be stated that the discussion below therefore touches on material not directly related to John, but does have a direct link to Johannine research. The aim is to position John within these discussions and not to contribute to these discussions as such, or to give a comprehensive discussion of these issues. ${ }^{10}$

Africa is a vast and diverse continent. No wonder that the academic tradition in the South for several reasons ${ }^{11}$ has a different history and development than that of the area north of Southern Africa. Consequently, the academic activities to the north of Southern Africa are usually considered separately from developments in Southern Africa and rightly so; their histories, focus of research, interests and developments differ. This is also one of the notable characteristics of Johannine research in Africa. ${ }^{12}$ In this article the developments of these

\footnotetext{
8.1 used the normal databases on research but went further. I also tried my best to be as inclusive as possible, writing letters to colleagues all over Africa asking for information regarding Johannine research in their areas - a friend of friends-type information regarding Johannine research in their areas - a friend of friends-type
of approach. I got good responses from many colleagues whom I would like to thank in this way.

9.I did include selected research where there is no specific reference to John in the title, but which deals with John in a notable way.

10.It should be noted that this article deals with developments in Johannine research in Africa, and not in general with developments in New Testament or biblica studies. In some cases there were developments that did not affect Johannine research and these will not be discussed.

11.Reasons relate to political situations (inter alia also the presence of apartheid) geographical distances and the high costs and difficulty to travel; differences in academic facilities; social and cultural differences; et cetera.

12.In the best bibliography on New Testament publications in Africa (that of LeMarquand) most of the southern research is left out, while the South was largely excluded from projects like the Africa Bible commentary, et cetera.
}

two areas will be treated separately. Obviously there are many similarities and overlaps between research in the North and South, which will become evident from the descriptions that follow. ${ }^{13}$

In Africa an emerging theological ethos is developing with an own identity. ${ }^{14}$ This indigenous African ${ }^{15}$ academic tradition $^{16}$ is relatively young, ${ }^{17}$ since western academic traditions dominated the academic and intellectual stage in Africa during the colonial period, which only ended about 20 years ago. ${ }^{18}$ These new traditions aim at developing a theological ethos that has its primary roots in Africa and not in western academic ethos. Not until recently, after the gradual decline of the colonial period in Africa, ${ }^{19}$ did the formation of an independent academic tradition started to dawn in Africa. ${ }^{20}$ Ukpong (2000:12) dates the start of the tradition to the 1930 s of the previous century, ${ }^{21}$ whilst the first books by independent African scholars started to be published only in the late 1940s. This 70-80 year old African academic tradition now wants to emphasise and celebrate their African identity and freedom in their approach to the Bible.

13.Significant work in reading the Bible authentically in Africa was done at the University of KwaZulu-Natal (West, Draper and others) and the University of Botswana (Dube).

14.The views of Maluleke (2000:94-95) in this regard are relevant. He cautions against using the term 'African biblical scholarship' as if it forms an equivalent to the western type of scholarship. African biblical scholars do lay emphasis on the Bible but appropriate it within a much larger framework, including different disciplines like Philosophy, Missiology or Systematic Theology. Within this framework there is also less specific and systematic focus on single aspects of biblical research.

15.Cf. the strong views of Maluleke (1999:1-3). Wendland (1999:3) mentions that there are 2000 languages in Africa alone, not to speak of the great differences in history or customs, between the partilineal-patrilocal and matrilineal-matrilocal peoples of Central Africa. There are nevertheless certain prominent scholars who still have no hesitancy to keep on referring to African religion or theology in the singular, like Mbiti (1969; 1986), Paris (1995), Kalu (1999:8). Adamo (2001:8-22) refers to an 'African worldview' or 'African indigenous tradition' in the singular although he concentrates on the Yoruba people of Nigeria. Maluleke (1999:2) however, attacks the singular use when it comes to the forms of Christianity in Africa: "works with such titles as "Christianity in Africa", "African Christian

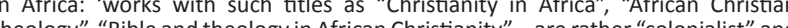
"theology", "Bible and theology in African Christianity"... are rather "colonialist" and "modernist" in scope'. Different people try to solve this problem in different ways. diverse in cultural form yet united in their underlying spirituality'.
deoples ... are

16.This is meant in the traditional sense of universities, colleges or similar institutions. Obviously the intellectual tradition goes back for hundreds of years, although this was mainly transmitted in an oral way.

17. Excluding the ancient Alexandria, as well as the older 'white' universities in South Africa, the University of Fort Hare is regarded by many as the oldest institution of tertiary education in Africa. It is little more than 100 years old (including its embryonic stage), going back to its earliest beginnings as missionary institution. Paris (1995:166) argues that serious studies of African culture by African scholars only started in the 1960s. Avotri (2000:315) mentions an interesting point. He refers to the lew to the low level of critical reflection in African biblical interpretation. Following Abogunrin, he explains that the missionaries did not bring critical reflection in the true academic sense of the word to Africa, which is today still evident in some of the seminaries. This means that the development of the academic tradition in
Africa is largely dependent on people who studied abroad.

18.Mugambi (1999:4) traces this to the Berlin Conference back in 1884-1885. See also the numerous books by missionaries or academics from western tradition describing the intellectual and cultural situation in Africa. Words like 'primitive', 'naturalistic', and other are common in these descriptions.

19.The end of colonialisation in Africa started to dawn in 1957 with Ghana becoming independent and it reached its 'conclusion' with the election of a democratic government in South Africa in 1994. Ukpong (2000:12) distinguishes three dominant phases of development, which according to him, started in the 1930s.

20.In South Africa these traditions go back 30-40 years with the writings of Tutu, Boesak, Mosala, Maluleke, and others. Paris (1995:1-3) refers to similar changes in the USA over the past few decades. He refers to these scholars as the 'new in the USA

21. He is obviously excluding the work done in the southern part of Africa, focusing more on the development of an African tradition that distinguishes itself from the predominantly western approaches that were practiced in the South. 
The task on hand is to strip the reading of the Bible from its colonial flavour without losing the presence and influence of the Christian document that came with the colonial powers (cf. the multiple publications of Dube in this regard). A clear vision and concrete efforts are indeed made to move beyond the western academic heritage to an independent and indigenous form of interpretation of the Bible. ${ }^{22}$

In dealing with these developing African traditions that also impact on John, the diversity of efforts of reading the Bible in Africa (efforts which often have an experimental quality to it), as well as a hermeneutical consciousness and a methodological sensitivity should be noted.

In Africa the Bible is highly regarded (Maluleke 2000:94-95), as West (2000c:9) puts it: 'In the present the Bible is central to the lived faith of ordinary African Christians'. Reading the Bible should have existential value, touching the lives of people in a concrete ${ }^{23}$ way. This becomes evident in the academic activities of many African scholars, who focus on the existential applications of the biblical text in their particular African situations. This elevates African readings of biblical texts onto the level of particular hermeneutical issues, also in John. ${ }^{24}$

Although there are diverse suggestions for reading the Bible in Africa, ${ }^{25}$ most of them share an approach that can be called the inculturation of the text (inculturation reading). This approach was propagated by, for instance Ukpong (2000) and are accepted widely ${ }^{26}$ (examples specifically highlighting this approach in Johannine publications will follow this general explanation). It is a hermeneutical program of reading the text, since explicatio and applicatio tend to overlap. It is acknowledged that the reader is emerged in a particular culture (in this case the African culture[s]), has certain views of reality which may vary according to geographical, political, social situations, etc.), experiences reality in certain ways (i.e. poverty, urbanisation, loss of power, etc.) and brings all this subjective complexity by way of synthesis to the reading process. A process of 'reading with' is preferred to a 'reading from above' in which all readers engage on similar level with the text. In this process of 'reading with' the readers with their issues and contributions influence one

22.That is why there are so many different publications and such a variety of divergin opinions on 'reading the Bible in Africa' today - cf. the most recent book edited by Adamo (2006) in which he claims to offer the current stage of development of African biblical studies.

23.Concreteness, that is to experience something concretely, even and especially of the spiritual world, is inherently part of the African worldview. West (2000c) refers to Ukpong when he describes the essence of African worldviews, namely: ... general significant features that characterise the African world-view: a unitary view of reality, a divine origin of the universe and an integral connectedness between God, humanity and the cosmos, a sense of community in which people are because they are in relation to other people, and an emphasis on the concrete and pragmatic. Though not exhaustive, these features are common to most, if not all, African world-views (Ukpong 1995:8-9)' (p. 7).

24.Cf. numerous publications, like Dube (1992), Mautsa and Janse van Rensburg (2010), Mlingo (2009), Ngele (2011), and others.

25.For instance the hermeneutic of relevance (Van der Watt \& Voges 2000), African cultural hermeneutics (Adamo 1999), inculturation hermeneutics (Ukpong 2000) 'neo-traditional' hermeneutic or neo-indigenous biblical hermeneutic (West 2000c:10-13), et cetera.

26.Cf. also Chamango (1999:98-104); Igboaja and Ike (1990); Okure (1990). Adamo (1999) uses the term African cultural hermeneutics. another in their interpretations and thus their understanding of the text, inspiring their individual interpretations. As Ukpong (2000) points out:

The goal of interpretation is the actualization of the theological meaning of the text in today's context so as to forge integration between faith and life, and engender commitment to personal and societal transformation'. (p. 24)

Within this process, the historical or social data related to the original situation within which the text was written are also welcomed in different ways, but usually not in the sense of 'reading down or from above' (West 1999; 2000a; $2000 b ; 2000 \mathrm{c})$. In this process of reading the text the reader approaches the text as somebody who has needs and therefore asks specific questions. These questions or needs will serve as filter for reading the text and will determine the understanding and meaning of the text. It is therefore not a matter of understanding the text primarily within its original context, but understanding the text within the present context of the readers within their reading processes - the text must address the reader. ${ }^{27}$ In this way explicatio and applicatio synchronise with one another. 'Ordinary "readers" of the Bible do not simply consume the product, they partially constitute both the process and the product' (West 2000c:5). In this way the reader becomes constitutive for the interpretation of the text. As Ukpong (2000:23) puts it: 'the resources of the people's culture and historical life experience are used as complementary to conventional critical tools of biblical exegesis'.

Suggestions exit on how to incorporate historical and social material into the reading process. West (1999; 2000a; 2000b; 2004), as one of the major authors on African hermeneutics, suggest that the material should be provided to the reading community to help them to get a feeling for the original framework of the text, but that should not hinder the process of 'reading with'. Within this context both scholars and nonscholars are involved, implying that an academic reading also impacts on the grass-root level (Okure 1993:77; West 2000a). In the words of West (2000c:4): 'The inclusion of ordinary African "readers" of the Bible in African biblical scholarship is acknowledged, whether implicitly or explicitly, by most African biblical scholars'. ${ }^{28}$ This also applies to Johannine readings of the text.

Van der Watt (1998a; 2000b; 2007b), in cooperation with Mahlangu and Ndwandwe, suggests a hermeneutic of relevance, specifically in relation to Johannine literature. This hermeneutical process is in line with what the inculturation reading suggests, namely that the reading process should start with what is relevant to the reader. From there communalities

27.Although not dealing with a Johannine text, Okure (1992a:221-230) illustrates how the suffering of the bleeding woman who 'borne the weight of illness, the alienation of society' (1992a:229) becomes the mirror in which the African woman may see herself, of course leading up to the healing process that restores her to wholeness. African women should follow this example, thus appropriating the biblical story to the benefit of the concrete African situation.

28.Dube (1996c) describes an interesting process in which the rhythmic cyclical harmonic movement of interpreting the text by moving from one point to another that was suggested in the previous point, constitutes a continuous process of communal interpretation. 
between the text and the reader should be identified to serve as basic point of departure in connecting reader and text, thus drawing the reader into the text. This makes it possible for the text to be explained within its original framework, which will challenge the readers to compare their own views with that of the text, identifying similarities and differences. In this way the reading process becomes a hermeneutical process of dialogue based on relevance.

What is also notable in Johannine research is the number of publications that applies to accepted exegetical procedures for reading a text, but nevertheless expresses the clear intention to make the information available to the readership in Africa. In 1992 Manus addressed the problem of the feeding of the crowd in John 6 (and its parallels) from an African perspective, thus trying to create an African hermeneutical framework for addressing a more 'orthodox' problem. At the turn of the century, Manus (2002) wrote an article entitled, 'Reconstructing Christology for Africa of the 21st century', illustrating the willingness of African theologians to be part of the academic discussions, but also to rethink the significance of Jesus specifically for Africa. In the same spirit Bidzoga (2006:33-45) discusses Jesus as the way to the Father (Jn 14:1-14) and then links it to the situation in Africa. This is evident even from the title of his contribution, namely 'Jesus, the way to the Father in John 14:1-14: A link with the African situation today'. ${ }^{29}$

Within this framework mention must also be made of several commentaries that were written on Johannine material. As part of the African Bible Commentary, ${ }^{30}$ Ngewa (2006a; 2006b) were responsible for the Gospel and letters of John, obviously with western academic insights as part of the venture. Van der Watt (1997b; 2009c) also wrote several shorter commentaries on John's Gospel whilst Du Rand (1989b) was responsible for the commentary on John in the Verklarende Bybel and Okure (1998) in The international Bible commentary.

More specific contextual readings, relating the material to specifically located areas in Africa, with their own problems, myths, religious narratives and expressions are also common. Kang (2003), for instance reads the story of Lazarus applying it specifically to the Malawian context. Dube (1992) again relates the biblical message to the Batswana women, making the important link between these women and the message of the Bible. ${ }^{31}$ Ngele (2011) relates the washing of the disciple's feet (Jn 13:1-17) to Jesus' servant leadership as model for the church and Nigerian society. The Akan myth, of the Akan people predominantly living in Ghana, is related to the resurrection of Lazarus as guiding narrative by Ahoua (2008), placing African narratives in relation to biblical narratives, investigating the parallels, and thus seeking an interpretative

29.Van der Watt (1998a) reads the Gospel from a specific African perspective, expressing the importance of relating the academic process to the African situation. Folarin (2001) also emphasises the importance of the link between exegesis and Folarin (2001) also emphasises the importance of the link between exegesis and
application in the African situation. This approach he also illustrates in Folarin (2002). Cf. further also Asante (2001); Du Rand (2002a; 2002b); Dube (2001); Kinoti (1999); Manus (1992); Nwigure (2003); Umoh (2005); Waweru (2008).

30.South Africans were largely excluded from this project.

31.Cf. also Chamango (1999). bridge. In his concluding sentence he remarks: '... we have shown a path for further development of African Christian theology (italicisation - JvdW), particularly for inculturation' (2008:185). In a different way and with different questions Lombard (1998) draws some inspiration from the Gospel of John in addressing orthodoxy and the other-worldliness of the church within a South African (predominantly white) society.

Another characteristic line of interpretation should be noted. In a situation of transition (i.e. political 'colonialism' from an African perspective only came to an end in 1994 with the end of apartheid in South Africa) theologies of reaction (i.e. black theology, liberation theology [cf. Mosala 1989],, feminism, etc.) are to be expected, and Africa is no exception. This means that the focus falls on biblical texts that evidently support the issue in question and motivate people to continue with the endeavours and struggles related to the issue in question. ${ }^{33}$

Obviously, certain books of the Bible could be better used in certain ways, addressing certain topics than others. The Gospel of John is no exception. Several issues drew African scholars to the Johannine text, for instance the emphasis on women, the issue of HIV and AIDS and the plight of such people, or the focus on life in abundance, based on the African lust for life.

A characteristic of African biblical interpretation is the presence of very capable female New Testament scholars, inter alia focusing on the plight of African women interpreted in the light of biblical material. Focus on the presence of women in the Johannine literature, sometimes with a feminist slant, is found. Passages like John 4 (the Samaritan woman), or John 7 (the woman caught in adultery - cf. Omotoye 2006:300-308), Jesus' relation to Mary Magdalene (Okure 1992b:177-188), the narrative of the anointment (Jn 12) or even the mother of Jesus (cf. Okure 1995:196-210 and the South African New Testament scholar Nortjé-Meyer 2009:123-143) provided a powerful message for women in Africa and received due attention by African women theologians.

Perhaps the best known work by an African woman on John 4 is that of Teresa Okure. John 4 has a paradigmatic function for the concept of mission according to John, being 'a miniature of the whole Gospel' (Okure 1988:56). ${ }^{34}$ Okure (1993:77) is also of the opinion that the reading of the text for African women includes both scholars and non-scholars, which says something about her hermeneutical approach. Texts should be read by exploiting their affective nature, serving as instruments that could encourage women who find themselves in degrading or less than acceptable situations. Dube, a theologian from Botswana, also explored the narrative of the Samaritan woman extensively. Dube (1992:5-9) wrote an article entitled, 'Jesus and the Samaritan

32.The text of John was not used with any frequency when it came to political issues.

33.The biblical defence of apartheid can in this sense also be seen as a reaction theology.

34.Cf. Köstenberger (1998:14-15) for an evaluation of Okure's approach. 
woman: A Motswana feminist theological reflection on woman and social transformation', signalling her interest in reading John's Gospel with the women of Africa with the aim of improving their situation through involvement with the biblical text. This was indeed a sign of things to come. In 2001 Dube developed this theme further by consciously bringing the Samaritan woman and African women under the same umbrella, whilst in her article in 2002 she reads John 4 for decolonisation, a process to be reflected on in the postcolonial situation in Africa (cf. also her books in 1998 and 2000a on postcolonialism, also reflecting on John). The role of the Samaritan woman was even explored within the framework of leadership, an important issue for African woman in the light of a patriarchal social framework. As far back as the 1980s Manus (1987:52-63) already explored the narrative of the Samaritan woman on the basis of which he discusses female leadership and nation building in Africa. The focus of Mautsa and Janse van Rensburg (2010:1-18) are likewise on the Samaritan woman as leader. ${ }^{35}$ Nwaigbo (2006:3857) took a different approach, focussing on interreligious dialogue in the third millennium, but also finding guidance and inspiration for Africa from the narrative of the Samaritan woman.

Interestingly enough John 10:10 (Jesus 'came that they may have life and have it abundantly') also encourages African readers of the Bible. John 10:10 became a popular text to enrich the zest for life that is part of Africa. In a continent where poverty and hardship is not unknown to the majority of people, the promise of abundant and of course good life is always welcome. Prosperity preachers therefore like to make use of this verse, as Mbamalu (2010) points out. Owan (1996:18-42) applied this verse to justice within a liberation context. The right of life belongs to everybody and Jesus assures that (cf. also Gitari 1996:128-130; Kabongo-Mbaya s.a.:67-77). Sindima (1990:50-62) also made the fullness of life his concern, arguing the issue from the perspective of the Logos in the Prologue.

A more specific but dire problem in Africa is HIV and AIDS. There are people to whom the Johannine message is one of hope (Mligo 2009). People from certain countries in Africa suffer from the largest Aids infection in the world. ${ }^{36}$ Since African people have a holistic view of reality in which spiritual power plays an important role in the healing process, the Bible, as their source of power, is obviously looked at for help. Omotoye (2006) uses the narrative of the Samaritan woman to call for the embracement of HIV and AIDS patients in Nigeria, underlining the need for social change of attitude towards people who suffer from this disease. Kgalemang (2004:141-168) and Mligo (2009) also deal with the stigmatisation of HIV and AIDS sufferers from a

35.Cf. also Waweru (2008:139-160) and Cornelius (2008:69-87) for the attention the Samaritan woman gets when reading John in Africa. Cf. also Du Rand (2000).

36.In 2011 there were nearly 23 million HIV infected people in sub-Saharan Africa, and this number is growing, inter alia because of better treatment (patients live lond the longer). Of these, nearly three millon were children. In the South (Botswana, Lin infected, while nearly $18 \%$ of South Africans ( 5.6 million) suffer from the disease. Zimbabwe and Zambia are not far behind. Cf. for detailed statistics: http://www. avert.org/africa-hiv-aids-statistics.htm
Johannine perspective and then formulate a message of hope from John's Gospel for those who find themselves in this situation. The article of Togarasei (2011), focusing specifically on Pentecostal churches in Botswana, gives a good survey of the use of the Bible related to the problem of HIV and AIDS and shows that amongst many biblical sections John 13:34-35 is used to encourage love towards sufferers of HIV and AIDS.

It should also be noted that scholars from the northern parts of Africa did not only publish with Africa in mind, but also interacted with the discussions taking place on international level according to the rules of the international (western) guild. These types of research will be discussed in more detail later on with research predominantly done in the South. Some attention will also be given later on to research on the letters of John.

A last remark: since the reading process as is suggested by African hermeneutics integrates text and reader from the initial stages of the reading process, it often creates some tension with western guilds who often tend to distinguish between different stages in the process of interpretation, first trying to read the text as far as possible within its context of origin and then move towards understanding the implications of the texts through a intricate hermeneutical process. It is often felt that neither the initial interpretation of the text within its context of origin, nor the more refined hermeneutical applications are sufficiently honoured in the African approaches. Within the guild this tension needs to be addressed, because the western interpretations are also not without strong subjective inputs and agendas.

\section{Research predominantly done in the Southern part of Africa}

The development of Johannine research in most of the Southern parts of Africa was mostly in tandem with western developments, although it has its own particular emphases. It must be remembered that the university tradition in South Africa is nearly 200 years old, considerably older than in the rest of Africa. These universities were initiated within the colonial framework, which characterised the academic ethos that was mainly orientated towards the West. ${ }^{37}$

The first major Johannine research by an African in the past 40 years that should be mentioned is the much quoted work of W. Nicol (1972) on the semeia source. As doctoral dissertation completed at Kampen Theological University in Kampen, The Netherlands, it investigated the semeia as source, typical of the historical critical research interests in Europe at that time, especially under the influence of major Johannine researchers like Bultmann and Dodd. Since Nicol stayed in ministry and only did part-time teaching, the impact of this European published study remained limited in Africa compared to its influence in the rest of the guild.

37.In 1829 Cape Town opens its doors for tertiary education. The first steps for tertiary education in Stellenbosch were taken on 01 March 1866. In the northern part of South Africa the roots of the University of Pretoria goes back to 1908. Higher South Africa the roots of the University of Pretoria goes back to 1908. Higher
education in the Eastern Cape started in 1916 and developed into the current University of Fort Hare located at Alice. 
In the past 40 years two major sources of influence on Johannine research in South (-ern) Africa ${ }^{38}$ should be noted, namely, the New Testament Society of South Africa and the presence of Prof. Jannie Louw, ${ }^{39}$ one of the authors of the GreekEnglish Lexicon of the New Testament: Based on semantic domains (Louw \& Nida 1999), who introduced the New Testament guild in South Africa to linguistic and literary studies. This stimulated the interest of South African New Testament scholars in issues related to methods of interpretation, which were obviously based in hermeneutical interests. Linguistic and literary developments would therefore typify much of what was done in the past 40 years. ${ }^{40}$

Initially emphasis fell on the analysis of words or concepts, not the least since Louw's work on the Greek-English lexicon started in the 1970s and he involved his students and even colleagues actively in the development of the semantic theories, especially related to determining the meaning of words (the basis of lexicography). The focus on semantic domains instead of on translation equivalence offered new avenues for semantic analysis. A basic insight was that words do not have meaning, but are used in contexts where they acquire meaning. It was therefore obvious that the structure that offered insight into the context became a point of considerable interest. South African structural (discourse) analysis subsequently developed, leading to other literary issues like rhetoric, style, metaphorical use, and other issues (see below). The fruits of these activities and developments were subsequently reflected in Johannine research (as was the case with the rest of the New Testament also).

The initial interests were in word studies. For example Du Rand (1982a) determines the meaning of entole in the Gospel and letters of John, whilst van der Watt (1986) uses the semantic insights propagated by Louw to determine the meaning of the concept, eternal life, in the Gospel of John. Van der Merwe (1996a) focuses on the analysis of discipleship in the Gospel. In these studies both semantics, including the syntagmatic and paradigmatic use of words, as well as structural issues were combined in determining the semantics of these words in the Gospel.

During the 70s and 80s of the previous century (in parallel with what happened at the SBL - with Crossan and Funk analysing parables - and in the Scandinavian countries regarding structural analysis) Louw also initiated what came to be known as South African structural (discourse) analysis, ${ }^{41}$

38.Not only South Africa should be thought of, but also countries like Namibia and Botswana.

39.Obviously, Louw did not work alone, but succeeded in creating considerable interest among his students and colleagues in the then developing focus on literary studies and related methods.

40.The myth that the academic work in this time concentrated so much on literary studies because of apartheid and the fear to engage with the real political scen (cf., for instance the work of West) has little truth in it. Although not planned in that way, it was the focus on the meaning of the structure or metaphors of the biblical documents that highlighted the challenges of the biblical texts. Refuge was not sought in 1st century historical issues.

41.The name varied during the period of the development of the method, based on pericopes, cola and commata, which were linked in a binary way in order to describe the structure. Since the method was mainly applied to discourse materia (not so much to narratives) it was thought that discourse analysis would be a better way of describing this methodological procedure. which was enthusiastically embraced, applied and further developed by the South African New Testament guild. It was also actively pursued in the New Testament Society of South Africa (NTSSA) that also had a Johannine seminar where these insights found a willing home. A good example is the complete structural analysis of the letters of John by Jan du Rand (1982b; 1982c; 1982d), which is done on the basis of commata, cola and pericope, the classical way in which South African structural analysis was done. Van der Watt (1986; 1987b) and Tolmie (1993a; 1993b) also applied structural analysis to larger sections of the Gospel itself.

In all fairness it must be acknowledged that during this initial euphoria about the potential of structural analysis, there was some discomfort with the fact that different 'structures' were possible for the same texts. It did not offer an 'objective entrance' into the meaning of the text. Apart from this, the cyclical argumentative movement in John also problematised the desire to find proper systematic structures, not to mention the limited value of South African structural analysis when applied to narratives. In the latter case narrative analyses have proven the better structural method. This discomfort later grew to the extent that South African structural analysis lost its impact on New Testament studies and, of course, also on Johannine studies in South Africa.

The influence of Louw introduced a period in which reflection on methods, and to a lesser extent hermeneutical issues, became a dominant interest in South African Johannine studies and also dominated the activities of the NTSSA. The mid-1970 to mid-1990 issues of Neotestamentica, the journal of the NTSSA, recorded this development well.

Following the focus on the use of words within contexts (described in terms of structures), other related methods were also developed or applied to Johannine material (taken from literary studies in general). The interest in methodological questions grew rapidly in South Africa. Two distinct lines developed, also in Johannine research, namely more intense interest in literary issues and the application of social-scientific insights on John (due to contacts by South African scholars with the Context group as well as with Abe Malherbe, a key figure in the development of social readings of the New Testament).

On the literary level, the love relationship with structural (discourse) analysis cooled down a bit and the interests expanded to other literary methods, like narrative analysis, metaphor theories, speech act theories, rhetoric, and other interests (see below for discussions). These different literary methods were experimentally applied to the Johannine text.

Whilst the most significant contribution of the North, to my mind, lies with the development of inculturation readings, the most significant contribution from the South lies with the application and development of methodology in reading the text of John. Three major areas can be distinguished. 
- Narratology: Reference was already made to the South African structural analysis, which was also applied to Johannine literature (Du Rand 1980a; 1982b; 1982c; 1982d; Tolmie 1993a; 1993b; Van der Watt 1986; 2000a). Whilst considering the implications of structures in texts, it was realised that discourse analysis was not the best method to investigate narratives. The interest therefore shifted to narratology as a means to determine the way the text was structured. Du Rand took the lead in this regard by focussing on different aspects of narratology. He illustrates how characterisation (of Jesus) works (1985), points out the reader in the Gospel (1984), discusses the plot and point of view (1986), and considers the role of the reader in a narrative with John 4 as example (1988b). He also discusses narratological perspectives in John 9-10 and 13:1-38 (1990; 1991b; 1992; 2008; see also 2005). Du Rand's student and successor at the University of the Free State, Francois Tolmie continued and developed the narratological reading of John even further (cf.Tolmie 1992; 1995a). Focalisation, an important aspect of narratological analysis, was applied to John 13-17 by him (Tolmie 1991). Notable is also Tolmie's refined characterisation of God in the Gospel (1998; cf. also 2006 on the characterisation of Peter). The implicit reader was the topic of Lemmer's (1991) research. These developments were largely restricted to the South.

- Theory of metaphor and imagery: The spiritual and symbolic nature of the Johannine material is well-known and this aspect was developed in much detail by African scholars. Van der Watt (1992; 1995; 1998b; 1998c; 1999b; 2000a; 2000b; 2006a; 2007a; 2007b) analyses the surface metaphors in the Gospel of John, illustrating that imageries related to family matters are dominant. As people born of God, receiving eternal life, living in a relationship with the Father and the Son, the Johannine believers form a community of love (cf. also Moruthane \& Nortjé-Meyer 2008; Nortjé-Meyer 2007; Van den Heever 1992 and Van Zyl). Joubert (2007) also shows how the concept of Paraclete or Spirit is developed within the dynamics of metaphor. Other metaphors are also present but are not so dominant. Mburu (2010) links the metaphoric use of language in John to the Qumran literature.

- Application of diverse methods: As was mentioned, the NTSSA fell in love with methodology in the last quarter of the 20th century. This is also clearly reflected in the Johannine research. Botha $(1989 ; 1991 a)$ did some provocative research related to the style of John and challenged available approaches to Johannine style, suggesting a movement away from the traditional perceptions about the style of John in favour of the performance of the texts themselves (cf. Du Rand 1998; Van der Watt 2008b). He opted for a speech act reading to the text of John 4. Other stylistic features like irony (Botha 1991b; Van der Watt 2010), double entendre (Van der Watt 2004), repetitions and variations (Du Rand 1996; Van der Watt 2009b) and John as drama (Domeris 1983) were also investigated. Approaches focusing on the effect of the text on the reader (like rhetoric or reader response) were applied to the text of John (Du Rand 1988a; 2006; Van der Watt 2010; 2012a; Wendland 2007). A project focusing on detailed analyses of the grammar of John is also running (Van der Watt \& Caragounis 2009).

All these contributions in their own way formed part of the spear point of international Johannine research at their particular times. In this sense the Johannine research in Africa reflected a particular literary focus and thus contributed in its own way to international Johannine scholarship. This was not necessarily on the level of inculturation or indigenisation, but through the participation in developing international debates.

The second focus, though not so prominent as the literary approach, was on social readings of the text. Domeris (1991) was one of the first to use anthropological insights in interpreting the Gospel. In 1992 (cf. also 2008) Du Rand read the first farewell discourse from narratological and sociological [sic!] perspectives. Social-scientific insights proved to be of value to unlock the ethical dynamics of 1 John (Van der Watt 1999a). Social material was also used in interpreting the metaphors in the Gospel (Van der Watt 2000a). It is argued that metaphors are social phenomena that should be framed within its proper social framework. This line of research was subsequently taken further by Van der Merwe and his student, Snodderly (Snodderly \& Van der Merwe 2007) who explored the familial aspects of the ethics of 1 John as basis for understanding the ethical dynamics of John. Van den Heever (1999) used social-rhetorical techniques to find data in unexpected places. Worth mentioning is the PhD work of Muderwa (2008) completed at Unisa, where he gave a social-historical perspective of discipleship in John.

Linked to the focus on the text itself, that formed part and parcel of the structuralist and literary approaches, was the growing interest in the theology or message of John. Although the focus might have fallen on the structure or semantics of John, the theological implications of these academic investigations were consistently considered as part of the overall process of interpreting the text of John. In the rest of Africa there was natural interest in certain theological issues, partly due to the nature of African traditional religion and the issues dealt with in this religion. This resulted in certain topics being focused on in Africa as a whole like the following seven topics.

- Christology: The Gospel of John is about Jesus Christ. Without going into any detail here, it may be mentioned that the role of Christ was and still is a point of discussion in the African traditional religion, not the least because of the integration of Christ into the socio-religious systems of the African traditional religion where ancestors still play a structurally important role (cf. Van der Watt 2007b; 2008a). That might be the reason why several articles have a general approach to the Christology of John with some suggestion of adapting it to African situations. Manus (2002), for instance writes about reconstructing 
Christology for Africa of the 21st century, based on the narrative of the cleansing of the temple. Folarin (2002) focuses on the functionality of the Christology, which is one of the basic points of contention, namely how Christ does function in Africa. In the South, Du Rand (1980c) also explores new perspectives on the Christology of John and Van der Watt (1993b) addresses the issue of Jesus as God and man. There is a definite interest in Christology in general and indeed efforts to address this problem. Research that pays more specific attention to aspects of Christology is, for instance Gitari (1996) who surveyes Jesus as Good Shepherd, Lioy (2007) who looks at Jesus as Torah, Obielosi (2008) who wrote a monograph on the Servant of God, Mbachu (1996) who also wrote a monograph on Mario-Christology, or several scholars who gave attention to the Logos in the Prologue. ${ }^{42}$ Bidzoga (2006) touches the central nerve when dealing with John 14:1-14, where Jesus is described as the Way to the Father.

There is also above average interest in 'applied Christology', namely in Jesus as Saviour (cf. Dube (1996a). Both the crossevents (Mbaziba 1964; Van der Watt 1999c; 2003a) and the resurrection of Jesus (Adamo 1990; Kok 2009; 2011) are topics in African Johannine scholarship. How this resurrected Jesus is present in his community is addressed by Van der Watt (2002). This, of course leads to the important soteriological topic of eternal life. In the eighties Van der Watt (1985;1986; 1987a) published a series of articles suggesting that life is not a stagnant gift in John, but a way of living that life. Getting life means being taken up in fellowship with God and obviously living accordingly Ndayango (2001) addresses the relation between faith, life and miracles in John. This being the harvest of African theology on the central theme of John's Gospel, should encourage Africa to address these central issues anew.

- Pneumatology: The African worldview is essentially holistic in nature, implying that reality, both visible and invisible, forms an integrated whole in which different elements of this reality interrelate and mutually influence one another. The material reality is therefore in direct contact and is directly influenced by the spiritual reality, which consists of good and evil powers, ancestors, and the rest. These spiritual powers should be manipulated in favour of the physical person. Special emphasis on the power of God is therefore to be expected. It is indeed a central theme in the charismatic movements in Africa and these are the areas where Christianity experiences the biggest growth in Africa. Since the Spirit is in any case an important theme in John, several publications on the Spirit were written by South Africans who do not necessarily share the above worldview. These are diverse in nature (cf. Botha \& Tuppurainen 2008 on the roles of the Spirit; Draper 1992 on the soteriological role of the Spirit or Paraclete; Joubert 2007 on metaphors related to the Spirit; Van der Watt 2000b on the Spirit who gives

42.Cf. Atal La Augang Endziengn (1968), Sindima (1990) and Van Aarde and Ingram (2005) - they all focus on the Logos in the Prologue. life in African context). In 1991 Rwehumbiza wrote an article explaining how Jesus is actively present within his community. Osunwokeh $(2000 ; 2014)$ did the most extensive work on this topic of Johannine spirituality in his Nigerian dissertation. Having said this, I must confess that it remains strange to me, given the above importance of the Spirit(s) in Africa, that the theme of the Spirit in John is not explored in more detail specifically within an African context. There seems to be a big need for thorough study and discussion in this direction.

- Mission: The footprints of missionary activities are still clearly present in Africa. One of the basic theological structures in John is the mission of the Son and the subsequent mission of his disciples. This did not go unnoticed in Africa. No wonder that since the work of Okure $(1988 ; 1991)$ on mission in John there was a thin but constant stream of publications on this topic. Ituma (2006) completed a Nigerian PhD on mission in John's Gospel, continuing the interest in this topic in this part of the continent. Osunwokeh (2000) also frames his interpretation of the Spirit within the mission of Jesus. Fansaka Biniama (2004) looks at the mission of individual characters in John and focuses specifically on Mary Magdalene. In South Africa the interest is again building up in this regard. Van der Merwe (1998) points out that the mission of Jesus should be continued in his disciples. Kok (2011) and Smith (2011) also emphasise that a basic characteristic of Johannine Christianity is the missional dimension, which serves as basis for the transformation of communities.

- Ethics: One of the two main foci in the letters of John is the ethical dynamics (cf. Du Rand 1989a; Van der Watt 1988; 1999a), whilst in the Gospel the presence of ethics was questioned or at least played down considerably (cf. Van der Watt 2011c). In the South the ethics of John became an important theme, resulting in three international publications (Van der Watt 1993a; 1997a; 1999a; 2006a; 2006b; 2006c; Van der Watt \& Zimmermann 2012; Zimmermann \& Van der Watt 2010). By broadening the analytical categories used in identifying ethical material, it was illustrated that not only in the letters, but also the Gospel ethics is a basic theme (Van der Watt 2006c; 2011b; 2011c). On theoretical level the relationship between ethics and language (Van der Watt 2010) and imagery (Van der Watt 2006a; 2006d), as well as the cognitive structure within which ethics should be considered (Van der Watt 2011c) broke new ground. Some of the important themes that are considered are, love (Botha \& Rousseau 2005; Du Rand 1980b; Van der Watt 1988; 1993a; 1997a; Verster 2009), the idea of imitating Jesus by remembering him (Vergeer \& Janse van Rensburg 1999; Van der Merwe 2001), the importance of the commandments in John (Du Rand 1982a), and the interpretation of the Law (Van der Watt 2012a), the function of truth in ethics (Van der Watt 2009a), poverty (Makambu 2009), the ethics of work and rest (Draper 1999), and interestingly enough the way this Gospel of love deals with violence (Schaeffler 2006; Van der Watt \& Kok 2008a; 2008b; 2012). 
- Leadership: Another topic that is not systematically discussed, but does pop up every now and then, is leadership. As in some other cases, Manus (1987) was the first to address the topic. He asks the question about female leadership. Mautsa and Janse van Rensburg (2010) also look at a woman leader, namely the Samaritan woman. Ngele (2011) uses Jesus to consider the nature of servant leadership in Nigeria. There is some discomfort with leadership in Africa amongst some scholars and it could be expected that this topic will become increasingly important. Mahlangu of South Africa (ex-lecturer, University of Pretoria) is currently busy with a major project in this regard. Related to leadership, though not overlapping is the interest in discipleship in John. Magagula (1964) states that discipleship is a costly affair, but the major research in this area was done by Van der Merwe (1996a; 1996b; 1997; 2003b) and Tolmie (1995b).

Other less treated themes of interest are ecclesiology, ${ }^{43}$ soteriology, ${ }^{44}$ faith, ${ }^{45}$ and eschatology (Van der Watt 2011a):

- Most popular Johannine texts: The concept of a canon within a canon, focusing on certain parts of a biblical book is well known. What is the canon within the canon when it comes to John? Number one on the list seems to be the Prologue (John 1:1-18), with discussions of the Logos the most popular. ${ }^{46}$ Secondly, the narrative of the Samaritan woman (John 4) is high on the list of popularity, especially in dealing with issues related to woman. ${ }^{47}$ Thirdly, the farewell discourses with John 13 and 17 as focus also received due attention. ${ }^{48}$ Looking at the above, ${ }^{49}$ it could be positive for African scholars to expand their interest to other parts of this Gospel too, or perhaps consciously work together in interpreting the Gospel as a whole.

- Introductory questions: Introductory issues are often the way new students of John become acquainted with this Gospel. What happened in this regard in Africa? Both the important introduction to the Johannine literature of Du Rand (1991a; 1991b; cf. also 1994), as well as Van der Watt's (2007b) introduction to the Gospel and letters are used internationally as prescribed books. Van Aarde (1985) and Tolmie (1995a) deal with the evergreen question of who the author of the Gospel (and letters) was, whilst Magezi and Manzanga (2010) try to find the

43.Cf. Draper (1991), and (1997) regarding the temple; Olivier and Van Aarde (1991) regarding the house of God Suggit (1993) on worship and liturgy in John. Du Rand (1986) and Van der Merwe (2002) consider the unity of the church. Cf. also Arowelle (1991).

44.Adamo (1989); Ahoua (2008); Dube (1996a); Kok (2011); Van der Watt (1995; 2003b; 2005).

45.Adamo (1990); Du Toit (1991); Ndayango (2001); Van der Watt (2001).

46.Cf. Atal La Augang Endziengn (1968), Sindima (1990) and Van Aarde and Ingram (2005) who focuse on the Logos in the Prologue; Diouf (1999) who draws attention to the soteriology in John 1:11-13; and also Dube (2000b); Kinoti (1999); Tshehla (2003); and Van der Watt (1996).

47.Cf. Cornelius (2008); Dube (1992, 2001, 2002); Du Rand (2000); Manus (1987); Mautsa and Janse van Rensburg (2010); Nwaigbo (2006).

48.Cf. Du Rand (1980d; 1990; 1992); Tolmie (2008); Van der Merwe (2003a; 2004).

49.Cf. also the work done on John 6, by Kuzenzama (1979); Manus (1992); Zuzan (1983). most plausible background to the fourth Gospel. This is not a preferred area of research in Africa.

Specific mention should also be made of the research on the letters of John. Little is done in Africa in this area of research. Two areas were explored, namely the structure of the letters and the ethical dynamics in the letters. Although Johannine Christology is a relative popular topic of research in Africa (see discussion there) the Christological material in the letters did not receive due attention. ${ }^{50} \mathrm{Du}$ Rand, as part of a NTSSA project, was responsible for a series of publications on the structure (structural analysis) of the letters (1980a; 1982b; 1982c; 1982d; 1989a). The ethical dynamics of the letters, as one of the two main focal point of 1 and 2 John, did not escape notice. Van der Watt (1999a) argues that several ethical aspects of 1 John could be better understood within a communal family framework, using social-scientific insights. Love, as essential aspect of ethical behaviour in the letters is analysed by Van der Watt (1988), whilst Du Rand (1980b) argues that truth and love are key terms for understanding 2 John. The ethically related aspects of authority, conflict, and crisis $^{51}$ in 1 John are investigated by Umoh (2005). ${ }^{52}$ Noteworthy is also the treatment of the introductory issues related to the letters in Du Rand (1991b) and Van der Watt (2007b; 2011a; 2013). Virtually all the research on the letters was done in the South. This is an area that could prove fruitful for further research and mutual cooperation in Africa. Van der Watt (2000b) has illustrated the relevance of 1 John for Africans based on the relevance of the imagery used in the letters and this should be explored even further.

For the sake of clarity, it must be mentioned that the Africanness of the academic activities was by no means forgotten in the South. Much work was done at the University of KwaZulu-Natal that was already referred to. In Botswana Dube (1992; 1996a; 1996b; 2000a; 2001; 2002) made significant contributions in this regard, as already discussed. Several scholars at other South African institutions also took part in the debate, even in relation to John, just to mention Cornelius (2008); Draper (2003); Du Rand (2002a; 2002b); and Van der Watt (2000b; 2007b; 2008a) again. Dube (1992; 1996a; 1996b; $2000 b ; 2001$; 2002) has a specific interest in decolonised readings of John, which give a political colour to the reading of Johannine texts, not the least because Africa was politicised through colonisation (cf. also Draper 1991, who also addressed some political issues by referring to John).

Unfortunately, due to geographical and often political barriers, this research was not taken up in the main stream of the northern African discussions and neither was the

50.The article of Van der Watt (1993b) is one of the rare exceptions.

51.Du Rand (1987) also pays attention to the confessional conflict in the letters.

52.The rest of the research is characterised by its diversity, for instance Du Preez (1978) investigates the problematic expression, 'seed of God', in 1 John 3:9 and Van in Wonfession of $\sin$ (1 John 1:8-10) whilst Du Rand (1982a) describes the role of in confession of $\sin (1 \mathrm{John} 1: 8-10)$ whilst Du Rand (1982a) describes the role of entole [command] in the Gospel and letters. The way in which the status of the Johannine group is regenerated is analysed from a social scientific perspective by Snodderly and Van der Merwe (2007), whilst Wendland (2007) pays attention to the rhetoric of reassurance in 1 John. Cf. also Van der Merwe (2008) on the time in the letters and Van der Watt (2012b) on spirituality in 1 John. 
expertise of the 'South' used in projects like the African Bible Commentary. ${ }^{53}$ I am convinced that if Africa wants to develop an own character that could stand up against scrutiny from traditional or western academic traditions, this separation should be minimalised, or even better, be overcome.

Africa is a religious continent, with at least three big religions competing, namely African Traditional Religion, Christianity, and Islam. The theme of interreligious dialogue is therefore bound to come into focus. In this sense John with its strong emphasis on Jesus as the only Saviour, the Truth, Way and Life (John 14:6) is of course controversial. That might perhaps be the reason why I could only find two articles dealing with this issue from a Johannine perspective, namely Nwaigbo (2006) who uses the example of the Samaritan woman (Jn 4) to address the issue of interreligious dialogue. The second article is by Verster (2009) who sees love (Jn 3:16) as the entrance into interreligious dialogue, especially with Moslems. On this level the Johannine literature offers a challenge; the absolute Christological claims of John, the true meaning of the God of love, and the missiological drive in the Gospel should be thought through in its relation to the interreligious debate.

\section{Conclusion}

In the light of the above, the following six brief concluding remarks may be noted:

- Much of the Johannine studies reflect the desire of African scholars to read the text for and with Africa, that is inculturation reading. This is a hermeneutical program in which the division between academic study and grassroots readers are minimised. This is a dominant feature of studies north of Southern Africa, but it is not exclusively restricted to those areas.

- In the South (although also not exclusively) research followed the developments of the western guilds, with strong focus on literary methods, with the main emphasis on structural and metaphorical approaches.

- A major challenge of African Johannine scholarship (as well as New Testament scholarship in general) is to find hermeneutically valid and sound ways to combine western academic traditions and insights with a strong affective approach. Is a predominantly historical approach to the texts to be married with a decisive and immediate applicative reading of the text?

- Although Africa is starting to develop its own research community through $\mathrm{PhD}$ students that are trained locally, there are strong contacts with the academic training centres in the West. This will ensure the strong influence of the western academic ethos in Africa for the time being. This is not regarded as negative, since links with international guilds are still held in high regard. Attraction to and participation in western academic activities will continue due to the need of libraries (the libraries in Africa are 'young' and books are expensive, limiting the capabilities of African libraries) and the difficulty and high costs of travelling within Africa. It should, however, not discourage indigenous reflection, but rather encourage and refine it.

- Taken the number of publications on John on international level, the publication rate in Africa is very low. Areas where impact was made were mainly linked to particular individual persons (like mission: Okure; narrative: Du Rand and Tolmie; metaphors: Van der Watt; etc.). Except for hermeneutical and methodological similarities, a coherent African approach to Johannine material lacks. The need for more coordinated cooperation in the field of Johannine studies in Africa is indeed high.

- The important theological themes that receive attention in Africa mostly correspond with African needs. The lack of coordinated research on specific topics that are specifically related to Africa, however, needs to be actively addressed.

\section{Acknowledgements}

This article is dedicated to Jan du Rand, a friend and colleague, for his significant contribution to New Testament and specifically Johannine studies.

\section{Competing interests}

The author declares that he has no financial or personal relationship(s) that may have inappropriately influenced him in writing this article.

\section{References}

Adamo, D.T., 1989, 'Sin in John's Gospel', ERT 13(3), 216-227.

Adamo, D.T., 1990, 'Jesus' resurrection and his disciple's acceptance: An exegetical study of John chapter 20', Deletion Biblikos Meleton 19(2), 13-21.

Adamo, D.T., 1999, 'African cultural hermeneutics', in R.S. Sugirtharajah (ed.), Vernacular hermeneutics, pp. 66-90, Sheffield Academic Press, Sheffield.

Adamo, D.T., 2001, Reading and interpreting the Bible in African indigenous churches, Wipf \& Stock, Eugene.

Adamo, D.T. (ed.), 2006, Biblical interpretation in African perspective, University Press of America, Lanham.

Ahoua, R., 2008, The transference of the three mediating institutions of salvation from Caiaphas to Jesus: A study of Jn 11:45-54 in the light of the Akan myth crossing the river, Peter Lang, Bern.

Arowelle, P.J., 1991, 'The scattered children of God (John 11:52): A Johannine ecclesial cliché', in W. Amewowo, P. Arowele \& B. Balembo (eds.), Johannine communities, pp. 181-201, Catholic Faculty of Kinshasa, Kinshasa.

Asante, E., 2001, 'The Gospel in context: An African perspective', Interpretation 55(4), 355-366. http://dx.doi.org/10.1177/002096430005500402

Atal La Augang Endziengn, D., 1968, 'Le theme johannique du Logos: Structure et exégése du prologue de l'Evangile', PhD thesis, Faculty of Theology, University of Kinshasa, Kinshasa.

Avotri, S.K., 2000, 'The venacularization of Scripture and African beliefs: The story of the Garasene demoniac among the Ewe of West Africa', in G.O. West \& M.W. Dube (eds.), The Bible in Africa: Transactions, trajectories and trends, pp. 311-325, Brill, Leiden.

Bidzoga, G.R., 2006, 'Jesus, the way to the Father in John 14:1-14: A link with the African situation today', Hekima Review 35, 33-45.

Botha, J.E., 1989, 'A study in Johannine style: History, theory and practice', DTh thesis, Faculty of Theology, University of South Africa, Pretoria.

Botha, J.E., 1991a, Jesus and the Samaritan woman: A speech act reading of John 4:1-42, Brill, Leiden.

Botha, J.E., 1991b, 'The case of Johannine irony reopened', Neotestamentica 25(2), 209-232.

Botha, J.E. \& Rousseau, P.A., 2005, 'For God did not love the whole world - only Israel! John 3:16 revisited', HTS Hervormde Teologiese Studies 61(4), 1149-1168. http:// dx.doi.org/10.4102/hts.v61i4.479

Botha, J.E. \& Tuppurainen, R., 2008, 'The roles of the Spirit in John 16:4b-15: An integrated reading', Acta Patristica et Byzantina 19, 23-43. 
Chamango, S., 1999, 'Inculturation and the Gospel: A Mozambican perspective', International Review of Mission 88, 98-104. http://dx.doi. perspective', International Review of
org/10.1111/j.1758-6631.1999.tb00139.x

Cornelius, E., 2008, 'I heard the voice of the Samaritan woman in John 4:1-46', Nederduitse Gereformeerde Teologiese Tydskrif 49(3-4), 69-87.

Diouf, J.-N., 1999, 'La nouvelle renaissance dans le Prologue de Saint Jean (Jn 1, 11 13)', in J.-B. Matand Bulembat, P.D. Njoroge, L. Mhagama \& P. Zoungrana (eds.) The church as family and biblical perspectives, pp. 99-112, Catholic Faculty of Kinshasa, Kinshasa.

Domeris, W.A., 1983, 'The Johannine drama', Journal of Theology for Southern Africa $42,29-36$.

Domeris, W.R., 1991, 'The farewell discourse: An anthropological perspective, Neotestamentica 25(2), 233-272.

Draper, J.A., 1991, 'The Johannine community and its implications for a democratic society, in K. Nurnberger (ed.), A democratic vision for South Africa, pp. 115-136, Encounter, Pietermaritzburg.

Draper, J.A., 1992, 'The soteriological function of the Spirit/Paraclete in the farewell discourses in the fourth Gospel', Neotestamentica 26(1), 13-29.

Draper, J.A., 1997, 'Temple, tabernacle and mystical experience in John', Neotestamentica 31(2), 263-288.

Draper, J.A., 1999, “"My Father is working until now and I am working” (John 5:17): Reflections on a theology of work and rest', Bulletin for Contextual Theology 6(3), 43-47.

Draper, J.A., 2003, 'The closed text and the heavenly telephone: The role of the Bricoleur in oral mediation of sacred text in the case of George Khambule and the Gospel of John', in J.A. Draper (ed.), Orality, literacy and colonialism in Southern Africa, pp. 27-89, Brill, Leiden. (Semeia 46).

Du Preez, J., 1978, “'Sperma tou Theou” in 1 Joh 3:9', Neotestamentica 9(1), 105-112.

Du Rand, J.A., 1980a, 'Die ontsluiting van die struktuur van 3 Johannes met die oog op verdere eksegese', Skrif en Kerk 1(1), 33-47. http://dx.doi.org/10.4102/ ve.v1i1.898

Du Rand, J.A., 1980b, “'In waarheid en liefde ...": 'n Metodologiese sleutel tot die verstaan van die tweede Johannesbrief', Humanitas 5(4), 317-326.

Du Rand, J.A., 1980c, 'Nuwere perspektiewe in die studie van die Christologie van die Evangelie volgens Johannes', in A.B. du Toit (red.), Die Nuwe-Testamentiese wetenskap vandag, pp. 78-118, Universiteit van Pretoria, Pretoria.

Du Rand, J.A., 1980d, 'Eksegetiese kanttekeninge by Johannes 13', Scriptura 1(1), 43-52.

Du Rand, J.A., 1982a, Entole in die Johannesevangelie en -briewe, 2e uitg., NuweTestamentiese Werkgemeenskap in Suid-Afrika, Pretoria.

Du Rand, J.A., 1982b, 'A discourse analysis of 1 John', Neotestamentica 13, 1-46.

Du Rand, J.A., 1982c, 'The structure and message of 2 John', Neotestamentica 13 , 108-138.

Du Rand, J.A., 1982d, 'The structure of 3 John', Neotestamentica 13, 129-142.

Du Rand, J.A., 1984, 'Die leser in die Evangelie volgens Johannes', Fax Theologica 4(2), 45-63.

Du Rand, J.A., 1985, 'The characterisation of Jesus as depicted in the fourth Gospel', Neotestamentica 19, 18-36.

Du Rand, J.A., 1986, 'Plot and point of view in the Gospel of John', in J.H. Petzer \& P.J. Hartin (eds.), A South African perspective on the New Testament, pp. 149-169, Brill, Leiden.

Du Rand, J.A., 1987, 'Teologiese interpretasies in die leestellige konfliksituasies volgens die Johannesbriewe', Nederduitse Gereformeerde Teologiese Tydskrif 28(3), 142-152.

Du Rand, J.A., 1988a, 'Die betekenis van Martha se belydenis volgens die vertelling van Johannes 11:27', Fax Theologica 8(2), 30-39.

Du Rand, J.A., 1988b, "n Vrouedissipel uit Samaria? Lesergerigte eksegetiese opmerkings oor die vertelde gesprekke in Johannes 4', in J.C. Coetzee (red.),
Koninkryk, Gees en Woord: Huldigingsbundel vir L Floor, pp. 199-217, NGKoninkryk, Gees en Woord:
Kerkboekhandel, Pretoria.

Du Rand, J.A., 1989a, 'Johanneïese identifikasie: Etiese momente in die Johannesbriewe', Nederduitse Gereformeerde Teologiese Tydskrif 30(2), 29-47.

Du Rand, J.A., 1989b, 'Die Evangelie volgens Johannes', in E.P. Groenewald (red.), Die Verklarende Bybel, pp. 110-150, NG-Kerk-Uitgewers, Kaapstad.

Du Rand, J.A., 1990, 'Narratological perspectives in John 13:1-38', HTS Hervormde Teologiese Studies 46(3), 367-389. http://dx.doi.org/10.4102/hts.v46i3.2325

Du Rand, J.A., 1991a, 'Inleiding tot die Johannesevangelie', in A.B. du Toit (red.), Handleiding by die Nuwe Testament, deel 6, pp. 1-36, NG Kerkboekhandel, Pretoria.

Du Rand, J.A., 1991b, Johannine perspectives, Part 1: Introduction to the Johannine writings, Orion, Midrand.

Du Rand, J.A., 1992, 'A story and a community: Reading the first farewell discourse (John 13:31-14:31) from narratological and sociological perspectives', Neotestamentica 26(1), 31-45.

Du Rand, J.A., 1994, 'The Gospel according to John, and Revelation', in A.B. du Toit (ed.), Guide to the New Testament, vol. 6, pp. 1-29, 227-263, Lux Verbi, Wellington

Du Rand, J.A., 1996, 'Repetitions and variations: Experiencing the power of the Gospel of John as literary symphony', Neotestamentica 30(1), 145-156.

Du Rand, J.A., 1998, 'Reading the fourth Gospel like a literary symphony', in F.F. Segovia (ed.), What is John? Literary and social readings of the fourth Gospel, pp. 5-18, Scholars, Atlanta.
Du Rand, J.A., 2000, “"Because of the woman's testimony ...": Reading John 4 from a different angle', SA Baptist Journal of Theology 9, 1-10.

Du Rand, J.A., 2002a, 'Die Johannese logos kom opnuut tuis in Afrika', Verbum et Ecclesia 23(1), 80-91. http://dx.doi.org/10.4102/ve.v23i1.1205

Du Rand, J.A., 2002b, 'The Johannine Jesus in Africa?' in F. Segovia, A. Culpepper \& J. Painter (eds.), Word, theology and community in John: Festschrift $R$ Kysar, pp. 211-228, Fortress, Philadelphia.

Du Rand, J.A., 2005, 'The creation motif in the fourth Gospel: Perspectives on its narratological function within a Judaïstic background', in G. van Belle, J.G. van der Watt \& P. Maritz (eds.), Theology and Christology in the fourth Gospel, pp. 21-46, Brill, Leiden.

Du Rand, J.A., 2006, 'Bringing the reader into exegetical play, applied to the Gospel of John, in J.A. du Rand (ed.), More than one way of reading the Bible, vol, 2, pp. 51-142, University of Johannesburg, Johannesburg.

Du Rand, J.A., 2008, 'The Johannine "group" and "grid": Reading John 13:31-14:31 from narratological and sociological perspectives', in J. Verheyden (ed.), Miracles and imagery in Luke and John, pp. 125-139, Peeters, Leuven.

Du Toit, A., 1990, 'Sondebelydenis volgens 1 Johannes', Nederduitse Gereformeerde Teologiese Tydskrif 31(4), 520-525.

Du Toit, A., 1991, 'The aspect of faith in the Gospel of John with special reference to the farewell discourses of Jesus', Neotestamentica 25(2), 327-340.

Dube, M.W., 1992, 'Jesus and the Samaritan woman: A Motswana feminist theological reflection on woman and social transformation', Boleswa Journal of Occasiona theological Papers 1(5), 5-9.

Dube, M.W., 1996a, Saviour of the world but not of this world: A post-colonial reading of spatial construction in John, Scholars, Atlanta.

Dube, M.W., 1996b, 'Reading for decolonization (John 4:1-42)', Semeia 75, 37-59.

Dube, M.W., 1996c, 'Readings of Semoya: Batswana women's interpretations of Matt. 15:21-28', Semeia 73, 111-129.

Dube, M.W., 2000a, 'Batswaka: Which traveller are you (John 1:1-18)?', in G.O. West \& M.W. Dube (eds.), The Bible in Africa: Transactions, trajectories and trends, pp. 150-162, Brill, Leiden.

Dube, M.W., 2000b, Postcolonial feminist interpretation of the Bible, Chalice Press, St. Louis.

Dube, M.W., 2001, John 4:1-42, 'The five husbands at the well of living waters: The Samaritan woman and African woman, in N.J. Njoroge \& M.W. Dube (eds.), Talitha Cum! Theologies of African woman, pp. 40-65, Cluster, Pietermaritzburg.

Dube, M.W., 2002, 'Reading for decolonization (John 4.1-42), in M.W. Dube \& J.L. Staley (eds.), John and postcolonialism: Travel, space and power, pp. 51-75, Staley (eds.), John and postcolonialis
Sheffield Academic Press, Sheffield.

Fansaka Biniama, B., 2004, Les missions des individus johanniques: Le casde Marie de Magdala en In 20, Peter Lang, Frankfurt am M.

Folarin, G.O., 2001, The Gospel of John in African perspective, His love Publishers, llorin.

Folarin, G.O., 2002, 'Functional Christology in the fourth Gospel: Implications for African Christianity', African Journal of Biblical Studies 18(2), 22-38.

Gitari, D., 1996, 'The good shepherd: Ezekiel 34; John 10', in D. Gitari \& K. Bediako (eds.), In season and out of season: Sermons to a nation, pp. 128-130, Regnum, Carlisle.

Igboaja, E.U. \& Ike, O.F., 1990, Inculturation: Where do we stand? Lay apostolate Publishers, llorin.

Ituma, E.A., 2006, 'Mission in Johannine Gospel', PhD thesis, Department of Religion, University of Nigeria, Nsukka.

Joubert, J., 2007, 'Johannine metaphors/symbols linked to the Paraclete-Spirit and its theological implications', Acta Theologica 27(1), 83-104. http://dx.doi. org/10.4314/actat.v27i1.5493

Kabongo-Mbaya, P.B., s.a., 'Life in abundance: A biblical reflection on John 10:10', Reformed World, 67-77, viewed n.d., from http://warc.ch/24gc/study/01.pdf

Kalu, A., 1999, 'Interpreting the Biblical miracles with African traditional lenses', Paper read at SNTS-post conference, Hammanskraal.

Kang, J., 2003, 'The story of Lazarus (John 11:1-44): Reading from the Malawian context', Malawi Journal of Biblical Studies 1, 37-48.

Kgalemang, M., 2004, 'John 9: Deconstructing the HIV/AIDS stigma', in M.W. Dube \& M.R.A. Kanyoro (eds.), Grant me justice! HIV/AIDS \& gender readings of the Bible, pp. 141-168, Cluster, Pietermaritzburg.

Kinoti, H.W., 1999, 'John 1:1-18: An African perspective', in J.R. Levison \& P. PopeLevison (eds.), Return to Babel: Global perspectives on the Bible, pp. 145-150, Westminster John Knox, Louisville.

Kok, J., 2009, 'Die opstanding van Jesus as kulminerende genesingshandeling in Johannes', Verbum et Ecclesia 30(1), 112-147. http://dx.doi.org/10.4102/ ve.v30i1.66

Kok, J., 2011, 'The chaos of the cross as fractal of life: The birth of the post resurrection, missional dimension in John', Neotestamentica 45(1), 130-145.

Köstenberger, A.J., 1998, The missions of Jesus and the disciples, Eerdmans, Grand Rapids.

Kuzenzama, K.P.M., 1979, 'Jn 5-6 ou Jn 6-5? Une question embarrassante de critique Litteraire', Revue Africaine de Théologie 3(5), 61-69.

LeMarquand, G., 2000, 'A bibliography of the Bible in Africa', in G.O. West \& M.W. Dube (eds.), The Bible in Africa: Transactions, trajectories and trends, pp. 633800 , Brill, Leiden. 
Lemmer, R., 1991, 'A possible understanding by the implicit reader, of some of the "coming-going-being sent" pronouncements, in the Johannine farewell the 'coming-going-being sent pronouncem
discourses', Neotestamentica 25(2), 289-310.

Lioy, D., 2007, 'Jesus as Torah in John 2:1-22', Conspectus 4, 23-39.

Lombard, H.A., 1998, 'Orthodoxy and other worldliness of the church: Johannine perspectives on Christianity in a new South Africa', Neotestamentica 2(2), 497-508.

Louw, J.P. \& Nida, E.A., 1999, Greek-English lexicon of the New Testament: Based on semantic domains, United Bible Society, New York.

Magagula, S.J., 1964, 'John 8:17: The life of costly discipleship', Ministry 4(3), 125.

Magezi, V. \& Manzanga, P., 2010, 'A study to establish the most plausible background to the forth Gospel (John)', HTS Hervormde Teologiese Tydskrif 66(1), 7 pages.

Maluleke, T.S., 1999, 'African theologies/Christianities and the Bible - Some hermeneutical issues at stake', Paper read at SNTS-post Conference, Hammanskraal.

Maluleke, T.S., 2000, 'The Bible among African Christians: A missiological perspective', in T. Okure (ed.), To cast fire upon the earth: Bible and mission collaborating in today's multicultural global context, pp. 87-112, Cluster, Pietermaritzburg.

Makambu, A., 2009, “'Les pauvres, vous les aurez toujours avec vous” (Jn 12,8): Amour de Jésus versus service des pauvres?' in P. Bere, A. Kabasele, M.S. Nwachukwe \& A. Umoren (eds.), Poverty and riches in the Bible, pp. 213-237, Panafrican Association of Catholic Exegetes, Kinshasa.

Manus, C.U., 1987, 'The Samaritan woman (Jn 4:17 ff.): Reflections on female leadership and nation building in Africa', African Journa of Biblical Studies 2(1-2), 52-63.

Manus, C.U., 1992, 'John 6:1-15 and its synoptic parallels: An African approach toward the solution of a Johannine critical problem', Journal of the Interdenominational theological Centre 19(1-2), 47-71.
The

Manus, C.U., 2002, 'Reconstructing Christology for Africa of the 21st century: A rereading of Mark 11:15-19 and parallels: Matt. 21:12-17; Lk. 19:45-48; John 2:1322 ', African Journal of Biblical Studies 18(2), 1-21.

Mautsa, L.M. \& Janse van Rensburg, F.J., 2010, 'The Samaritan woman in John 4 as leader', Ekklesiastikos Pharos 92, 1-18.

Mbachu, H., 1996, Cana and Calvary revisited in the fourth Gospel narrative: MarioChristology in context, Hansel-Hohenhausen, Frankfurt.

Mbamalu, A.I., 2010, 'The use of "abundant life" in John 10:10 and its interpretation among some Yoruba prosperity gospel preachers', PhD thesis, Faculty of Theology, University of Natal.

Mbaziba, F.X., 1964, 'The death of Christ upon the cross as the supreme manifestation of God's love, in light of John xi,13', Doctoral dissertation, School of Theology, Pontifical University.

Mbiti, J.S., 1969, 'Eschatology', in K. Dickson \& P. Ellingworth (eds.), Biblical revelation and African beliefs, pp. 159-184, Lutterworth Press, London.

Mbiti, J.S., 1986, Bible and theology in Africcan Christianity, Oxford University Press, Oxford.

Mburu, E.W., 2010, Qumran and the origins of Johannine language and symbolism, Clark, London.

Mligo, E.S., 2009, Jesus and the stigmatized: Reading the Gospel of John in a context of HIV/AIDS-related stigmatization in Tanzania, PhD thesis, Faculty of Theology, University of Oslo.

Moruthane, S.W. \& Nortjé-Meyer, L., 2008, 'Family imagery in John', Ekklesiastikos Pharos 90, 81-97.

Mosala, I.J., 1989, Biblical hermeneutics and black theology in South Africa, Eerdmans, Grand Rapids.

Muderwa, V., 2008, 'A comprehensive reading of John 9: A socio-historical perspective of discipleship in the Gospel of John', PhD thesis, Department of Theology, University of South Africa.

Mugambi, J.N.K., 1999, 'An African approach to biblical hermeneutics', Paper presented at the SNTS-post conference, Hammanskraal.

Ndayango, A.C.C., 2001, Wunder, Glaube, und Leben bei Johannes: Eine exegetisch-hermeneutische Studie am Beispiel von Joh 3 im Hinblick auf die Inkulturationsaufgabe, Norbert, Bonn.

Ngele, O.K., 2011, 'Exegesis of John 13:1-17: Implication of Jesus' servant leadership model for the church and Nigerian society', Nsukka Journal of Religious and model for the church and
Cultural Studies 4(1), 64-86.

Ngewa, S.M., 2006a, 'John', in T. Adeyemo (ed.), Africa Bible commentary, pp. 12511296, Zondervan, Grand Rapids.

Ngewa, S.M., 2006b, '1+2+3 John', in T. Adeyemo (ed.), Africa Bible commentary, pp. 1529-1538, Zondervan, Grand Rapids.

Nicol, W., 1972, The semeia in the fourth Gospel: Tradition and redaction, Brill, Leiden. http://dx.doi.org/10.1163/9789004266148

Nortjé-Meyer, L., 2009, 'The “mother of Jesus" as analytical category in John's Gospel', Neotestamentica 43(1), 123-143.

Nwaigbo, F., 2006, 'Church in Africa and interreligious dialogue in the third millennium: Jesus and the Samaritan woman as a paradigm', Third Millennium 9(4), 38-57.

Nwigure, N.S., 2003, 'Johannine Christology: A critical analysis', in S.O. Abogunrin \& J.O. Akao (eds.), Christology in African context, pp. 195-203, Nigerian Association of Biblical Studies, Ibadan.

Obielosi, D.C., 2008, Servant of God in John, Peter Lang, Frankfurt am Main.

Okure, T., 1988, The Johannine approach to mission: A contextual study of John 4:142, Mohr Siebeck, Tübingen.
Okure, T., 1990, 32 articles evaluating inculturation of Christianity in Africa, AMECEA Gaba Publications, Eldoret.

Okure, T., 1991, 'Witnessing in the Johannine communities: A reflection paper', in W. Amewowo, P. Arowele \& B. Baslembo (eds.), Johannine communities, pp. 71-85, Catholic Faculty of Kinshasa, Kinshasa.

Okure, T., 1992a, 'The will to arise: Reflections on Luke 8:40-56', in M.A. Oduyoye \& M.R. Kanyoro (eds.), A will to arise: Woman, tradition and the church in Africa, pp. 221-230, Orbis, New York.

Okure, T., 1992b, 'The significance today of Jesus' commission of Mary Magdalene', International Review of Mission 81(322), 177-188. http://dx.doi. org/10.1111/j.1758-6631.1992.tb02294.x

Okure, T., 1993, 'Feminist interpretation in Africa', in E.S. Fiorenza (ed.), Searching the scriptures: A feminist introduction, pp. 76-85, Crossroads, New York.

Okure, T., 1995, 'The mother of Jesus in the New Testament: Implications for women in mission', Journal of Inculturation Theology 3(2), 196-210.

Okure, T., 1998, 'John', in W.R. Farmer (ed.), The International Bible Commentary, pp. 1438-1501, Liturgical Press, Collegeville.

Olivier, W.H. \& A.G. van Aarde, 1991, 'The community of faith as a dwelling-place of the Father: "Basileia tou Theou" as "household of God" in the Johannine farewell discourse', Neotestamentica 25(2), 379-400.

Omotoye, R., 2006, 'Jesus Christ and the adulterous woman: A case for embracing HIV/AIDS patients in Nigeria', in S.O. Abogurin \& J.O. Akao (eds.), Biblical view of sex and sexuality from African perspective, pp. 300-308, Nigerian Association of Biblical Studies, Ibadan.

Osunwokeh, C.I., 2000, 'Johannine pneumatology in the redemptive mission of Jesus Christ', PhD thesis, Department of Religion, University of Nigeria.

Osunwokeh, C.I., 2014, 'Bible interpretation, evangelization and faith: Nigerian context', Open Journal of Philosophy 4, 182-191. http://dx.doi.org/10.4236/ context', Open Jourr
ojpp.2014.42026

Owan, K.J.N., 1996, 'Jesus, justice and John 10:10: Liberation hermeneutics in the Nigerian context', Nigerian Journal of Theology 10(1), 18-42.

Paris, P.J., 1995, The spirituality of African peoples: The search for a common moral discourse, Fortress, Minneapolis.

Rwehumbiza, R.K.P., 1991, 'Presence and activity of the Holy Spirit in Johannine community', in W. Amewowo, P. Arowele \& B. Balembo (eds.), Johannine communities, pp. 202-241, Catholic Faculty of Kinshasa, Kinshasa.

Schaeffler, E., 2006, 'Jesus' non violence at his arrest: The synoptics and John's Gospel compared', Acta Patristica et Byzantina 17, 312-326.

Sindima, H.J., 1990, 'Moyo: Fullness of life - A hermeneutic of the Logos in John's Prologue', African Christian Studies 6(4), 50-62.

Smith, G., 2011, 'Witness in John 1-4: Towards an emerging, missiological church', Verbum et Ecclesia 32(1), 7 pages. online.

Snodderly, B. \& Van der Merwe, D.G., 2007, 'Status regeneration in first John: Social scientific and literary perspectives', Acta Patristica et Byzantina 18, 179-213.

Suggit, J., 1993, The sign of life: Studies in the fourth Gospel and the liturgy of the church, Galvin \& Soles, Cape Town.

Togarasei, L., 2011, 'The use of the Bible in HIV and AIDS contexts: Case study of some pentecostal churches in Botswana', in M.R. Gunda (ed.), From text to practise: The pentecostal churches in Botswana', in M.R. Gunda (ed.), From text to practise: The
role of the Bible in daily living of African people today, pp. 21-44, University of role of the Bible in daily livin
Bamberg Press, Bamberg.

Tolmie, D.F., 1991, 'The function of focalisation in John 13-17', Neotestamentica 25(2), 273-288.

Tolmie, D.F., 1992, Jesus' farewell to the disciples: John 13:1-17:26 in narratological perspective, Brill, Leiden.

Tolmie, D.F., 1993a, 'A discourse analysis of John 15:1-17', Ekklesiastikos Pharos 75(1), 54-79.

Tolmie, D.F., 1993b, 'A discourse analysis of John 17:1-26', Neotestamentica 27(2), 403-418.

Tolmie, D.F., 1995a, 'Die presbiter Johannes as outeur van die Johannesevangelie en -briewe?' Nederduitse Gereformeerde Teologies Tydskrif 35(3-4), 481-492.

Tolmie, D.F., 1995b, Farewell and discipleship: John 13:1-19:26 in narratological perspective, Brill, Leiden.

Tolmie, D.F., 1998, 'The characterization of God in the fourth Gospel', Journal for the Study of the New Testament 69(3), 57-75. http://dx.doi. org/10.1177/0142064X9802006903

Tolmie, D.F., 2006, 'The (not so) good shepherd: The use of shepherd imagery in the characterisation of Peter in the fourth Gospel', in J. Frey, J.G. van der Watt \& R. Zimmermann (eds.), Imagery in the Gospel of John: Terms, forms, themes and theology of figurative language, pp. 353-368, Mohr Siebeck, Tübingen.

Tolmie, D.F., 2008, 'Jesus, Judas and a morsel: Interpreting a gesture in John 13:21-30', in J. Verheyden, G. van Belle \& J.G. van der Watt (eds.), Miracles and imagery in Luke and John: Festschrift Ulrich Busse, pp. 5-125, Peeters, Leuven.

Tshehla, S.T., 2003, 'Colenso, John 1:1-18 and the politics of insider- and outsidertranslating', in J.A. Draper (ed.), The eye of the storm, pp. 29-41, Clark, London.

Ukpong, J.S., 2000, 'Developments in biblical interpretation in Africa: Historical and hermeneutical directions', in G.O. West \& M.W. Dube (eds.), The Bible in Africa: Transactions, trajectories and trends, pp. 11-28, Brill, Leiden.

Umoh, C., 2005, 'Authority, crisis and conflict in the Johannine community: An inculturation hermeneutic of 1 John', Journal of inculturation theology 7(1), 15-30.

Van Aarde, A.G., 1985, 'Die outeurskapsvraag van die Johannesevangelie met die oog op interpretasie of resepsie', Skrif en Kerk 6(1), 45-62. 
Van Aarde, A.G. \& Ingram, R., 2005, 'Van Plato tot Augustinus: Die vroeë Wirkungsgeschichte van die Logos-motief in Johannes', Ekklesiastikos Pharos 87 235-258.

Van den Heever, G., 1992, 'Theological metaphorics and the metaphors of John's Gospel', Neotestamentica 26(1), 89-100.

Van den Heever, G., 1999, 'Finding data in unexpected places: Towards a socio rhetorical reading of John's Gospel', Neotestamentica 33(2), 343-364.

Van der Merwe, D.G., 1996a, Discipleship in the fourth Gospel, Universiteit van Pretoria, Pretoria.

Van der Merwe, D.G., 1996b, 'A historical survey and critical evaluation concerning discipleship in the fourth Gospel', Skrif en Kerk 17(2), 427-442. http://dx.doi. org/10.4102/ve.v17i2.529

Van der Merwe, D.G., 1997, 'Towards a theological understanding of Johannine Discipleship', Neotestamentica 31(2), 339-359.

Van der Merwe, D.G., 1998, 'John 17: Jesus assigns his mission to his disciples', Skrif en Kerk 19(1), 115-127. http://dx.doi.org/10.4102/ve.v19i1.1157

Van der Merwe, D.G., 2001, 'Imitatio Christi in the fourth Gospel', Verbum et Ecclesia 22(1), 131-148. http://dx.doi.org/10.4102/ve.v22i1.628

Van der Merwe, D.G., 2002, 'The glory-motif in John 17:1-5: An exercise in biblical Semantics', Verbum et Ecclesia 23(1), 226-249. http://dx.doi.org/10.4102/ ve.v23i1.1250

Van der Merwe, D.G., 2003a, 'The exposition of John 17:6-8: An exegetical exercise', Hervormde Teologiese Studies 59(1), 169-190. http://dx.doi.org/10.4102/hts. v59i1.642

Van der Merwe, D.G., 2003b, 'Jesus appoints his disciples as his agents', Acta Patristica et Byzantina 14, 303-324.

Van der Merwe, D.G., 2004, 'The interpretation of the revelatory events in John 17:24-26: An exegetical exercise', Verbum et Ecclesia 25(1), 311-329. http:// dx.doi.org/10.4102/ve.v25i1.272

Van der Merwe, D.G., 2008, 'The past and future time in the present in 1 John', Acto Patristica et Byzantina 19, 290-328.

Van der Watt, J.G., 1985, 'A new look at John 5:25-29 in the light of the use of the term "eternal life" in the Gospel according to John', Neotestamentica 19, 71-86.

Van der Watt, J.G., 1986, Die ewige lewe in die Evangelie volgens Johannes, Universiteit van Pretoria, Pretoria.

Van der Watt, J.G., 1987a, '(A) Eternal life in John's Gospel: A denotative investigation', Nederduitse Gereformeerde Teologiese Tydskrif 28(4), 255-262.

Van der Watt, J.G., 1987b, 'Die strukturele komposisie van die Proloog van Johannes heroorweeg', Skrif en Kerk 8(1), 68-84.

Van der Watt, J.G., 1988, 'Broederliefde in 1 Johannes', in J.C. Breytenbach (red.), Kerk en konteks, pp. 65-76, NG Kerk-Uitgewers, Pretoria.

Van der Watt, J.G., 1992, 'Interpreting imagery in John's Gospel: John 10 and 15 as case Studies', in J.H. Barkhuizen, H.F. Stander \& G.J. Swart (reds.), Hupomnema: Feesbundel opgedra aan prof J P Louw, pp. 272-282, Universiteit van Pretoria, Pretoria.

Van der Watt, J.G., 1993a, 'Julle moet mekaar liefhê: Etiek in die Evangelie volgens Johannes', Scriptura S9a: Geloof en opdrag: Perspektiewe op die etiek van die Johannes', Scriptura S9a:
Nuwe Testament, 74-96.

Van der Watt, J.G., 1993b, 'Jesus, God of Mens!? 1 Joh 1:1-4 eksegeties oorweeg', NGTT 34(3), 275-292.

Van der Watt, J.G., 1999c, 'Die kruisgebeure volgens die Evangelie van Johannes', NGTT 40(2)

Van der Watt, J.G., 1995, 'Metaphorics in John 15', Biblische Zeitschrift 38(1), 67-80.

Van der Watt, J.G., 1996, 'Notas oor "Jode" en "Judisme" in die Evangelie volgens Johannes', Nederduitse Gereformeerde Teologiese Tydskrif 37(1), 193-207.

Van der Watt, J.G., 1997a, 'Liefde in die familie van God', Hervormde Teologiese Studies 53(3), 543-556.

Van der Watt, J.G., 1997b, 'Evangelie van Johannes', in Bybel met verwysings, pp. 1309-1347, Bible Society, Kaapstad.

Van der Watt, J.G., 1998a, 'My reading of 1 John in Africa', in I. Kitzberger (ed.), Personal voices in New Testament scholarship, pp. 142-155, Routledge, London.

Van der Watt, J.G., 1998b, 'The dynamics of metaphor in John's Gospel', Studien zum Neuen Testament und seiner Umwelt 23, 29-78.

Van der Watt, J.G., 1998c, 'Simbolisme in die Evangelie volgens Johannes', Skrif en Kerk 19(2), 392-403.

Van der Watt, J.G., 1999a, 'Ethics in 1 John: A literary and socioscientific perspective', Catholic Biblical Quarterly 7(3), 1-21.

Van der Watt, J.G., 1999b, 'Die gebruik van metafore in Psalm 80 (79-LXX) in vergelyking met Johannes 15:1-8', Skrif en Kerk (20)2, 445-464. http://dx.doi. org/10.4102/ve.v20i2.612

Van der Watt, J.G., 2000a, Family of the King: Dynamics of metaphor in the Gospel according to John, Brill, Leiden.

Van der Watt, J.G., 2000b, 'The Spirit gives life: Reading 1 John in African context', Protokolle zur Bibel 9(1), 1-22.

Van der Watt, J.G., 2001, '“Glo jy?” Johannes 20:28-31 - eksegetiese en homiletiese opmerkings', Nederduitse Gereformeerde Teologiese Tydskrif 42(3-4), 444-452.

Van der Watt, J.G., 2002, 'The presence of Jesus through the Gospel of John', Neotestamentica 36(1-2), 89-95.
Van der Watt, J.G., 2003a, 'The cross/resurrection-events in the Gospel of John with special emphasis on the confession of Thomas $(20: 28)$ ', Neotestamentica $37(1)$, 127-145.

Van der Watt, J.G., 2003b, 'Waar is God werklik? Redding in die Evangelie volgens Johannes', Nederduitse Gereformeerde Teologiese Tydskrif 44(3/4), 586577.

Van der Watt, J.G., 2004, 'Double entendre in the Gospel according to John', in G. van Belle, J.G. van der Watt \& P. Maritz (eds.), Christology and theology in the Gospel of John, pp. 463-481, Peters, Leuven.

Van der Watt, J.G., 2005, 'Salvation in the Gospel according to John', in J.G. van der Watt (ed.), Salvation in the New Testament: Perspectives on soteriology, pp. 101131, Brill, Leiden. http://dx.doi.org/10.1163/9789047407102_006

Van der Watt, J.G., 2006a, 'Ethics alive in imagery', in J. Frey, J.G. van der Watt \& R. Zimmermann (eds.), Imagery in the Gospel according toJohn/Bildersprache im Johannesevangelium, pp. 421-448, Mohr Siebeck, Tübingen.

Van der Watt, J.G., 2006b, 'Radical social redefinition and radical love: Ethics and ethos in the Gospel according to John', in J.G. van der Watt (ed.), Identity, ethics, and ethos in the New Testament, pp. 107-134, De Gruyter, Berlin. http://dx.doi. org/10.1515/9783110893939.107

Van der Watt, J.G., 2006c, 'Ethics and ethos in the Gospel according to John', Zeitschrift für die Neutestamentliche Wissenschaft 97(2), 147-176. http://dx.doi. org/10.1515/zntw.2006.012

Van der Watt, J.G., 2006d, 'Die implikasies van die familiebeeld in Johannes 8 vir die etiek van die Evangelie volgens Johannes', Ned Geref Teologiese Tydskrif 47(3/4).

Van der Watt, J.G., 2007a, 'The Father shows the Son everything: The imagery of education in John 5,19-23', Acta Patristica et Byzantina 18, 263-276.

Van der Watt, J.G., 2007b, 'A hermeneutics of relevance - Reading the Bible as dialogue in African contexts', Nederduitse Gereformeerde Teologiese Tydskrif 48(3-4), 50-61.

Van der Watt, J.G., 2008a, 'Reading the Bible in (South) African context: Hermeneutical considerations', in J. Verheyden \& G. van Belle (eds.), Miricale and imagery in Luke and John: Festschrift for Prof Ulrich Busse, pp. 237-258, Peeters, Leuven.

Van der Watt, J.G., 2008b, 'Johannine style Some initial remarks on the functional use of repetition in the Gospel according to John', In die Skriflig 42(1), 75-100. http:// dx.doi.org/10.4102/ids.v42i1.258

Van der Watt, J.G., 2009a, 'The good and the truth in John', in E. Poplutz (ed.), Studien zu Matthäus und Johannes/Études sur Matthieu et Jean, Festschrift für Jean Zumstein, pp. 317-333, Theologische Verlag Zürich, Zürich.

Van der Watt, J.G., 2009b, 'Repetition and functionality in the Gospel according to John: Some initial remarks', in G. van Belle \& P. Maritz (eds.), Repetition and variation in the Gospel according to John, pp. 87-108, Peeters, Leuven.

Van der Watt, J.G., 2009c, 'Evangelie volgens Johannes', in W. Vosloo \& J. Janse van Rensburg (reds.), Bybellenium: Eenvolume kommentaar, pp. 1314-1370, Christelike Uitgewersmaatskappy, Vereeniging.

Van der Watt, J.G., 2010, 'Ethics through the power of language: Some exploration in the Gospel according to John', in J.G. van der Watt \& R. Zimmermann (eds.), Moral language in the New Testament, pp. 139-167, Mohr Siebeck, Tübingen.

Van der Watt, J.G., 2011a, '1,2,3 John', in M.D. Coogan (ed.), The Oxford Encyclopedia of the books of the Bible, vol. 1, pp. 472-477, Oxford University Publishers, Oxford.

Van der Watt, J.G., 2011b, 'The Gospel of John's perception of ethical behavior', In die Skriflig 45(2 \& 3), 431-447.

Van der Watt, J.G., 2011c, 'Thou shalt ... do the will of God': Does the New Testament have anything to say for today?, Radboud University Nijmegen, Nijmegen.

Van der Watt, J.G., 2012a, 'Mag deur taal in 1 Johannes', HTS Hervormde Teologiese Studies 68(1), Online art. \#1196, 8 pages.

Van der Watt, J.G., 2012b, 'Aspects of spirituality as it is reflected in 1 John', Studies in Spirituality 22, 89-108.

Van der Watt, J.G., 2013, Wie was Gaius?, Nederduitse Gereformeerde Teologiese Tydskrif 54(1-2), 11 pages.

Van der Watt, J.G. \& Caragounis, C., 2009, 'The grammar of John 1:1', Filologia Neotestamentaria 22, 1-52.

Van der Watt, J.G. \& Kok, J., 2008a, 'Geweld in die Evangelie van liefde: Die perspektief van die Evangelie van Johannes op geweld teen Jesus en sy dissipels', Hervormde Teologiese Studies 64(4), 1793-1812. http://dx.doi.org/10.4102/hts. v64i4.99

Van der Watt, J.G. \& Kok, J., 2008b, 'Die reaksie van Jesus en sy dissipels op geweld in die Evangelie van Johannes', Hervormde Teologiese Studies 64(4), 1813-1835.

Van der Watt, J.G. \& Kok, J., 2012, 'Violence in a Gospel of love', in P.G.R. de Villiers \& J.W. Henten (eds.), Coping with violende in the New Testament, pp. 151-183, Brill, Leiden. http://dx.doi.org/10.1163/9789004221055_009

Van der Watt, J.G. \& Voges, L., 2000, 'Metaforiese elemente in die forensiese taal in die Evangelie volgens Johannes', Skrif en Kerk 21(2), 387-405.

Van der Watt, J.G. \& Zimmermann, R., 2012, Rethinking the ethics of John, Mohr Siebeck, Tübingen.

Van Zyl, C. \& Nortjé-Meyer S.J., 2007, 'Footwashing as a family event in John 13:1-20', Ekklesiastikos Pharos 89, 341-351.

Vergeer, W.C. \& Janse van Rensburg, F., 1999, 'Die Johannesevangelie as herinneringsboek', In die Skriflig/In Luce Verbi 33(1), 39-64. http://dx.doi. org/10.4102/ids.v33i1.1666 
Verster, P., 2009, 'Die liefde van God as aanknopingspunt vir'n gesprek met Moslems: Die rol van Joh 3:16', Acta Theologica 29(2), 151-168.

Waweru, H.M., 2008, 'Jesus and ordinary woman in the Gospel of John: An African perspective', Swedish Missiological Theme 96(2), 139-160.

Wendland, E., 1999, 'Contextualized translations and readings of the new Testament in Africa', Paper presented at the SNTS-post conference, Hammanskraal.

Wendland, E., 2007, 'The rhetoric of reassurance in first John: "Dear children" versus the "antichrist"', Neotestamentica 41(1), 173-219.

West, G.O., 1999, The academy of the poor: Towards a dialogical reading of the Bible, Sheffield Academic Press, Sheffield.

West, G.O., 2000a, 'Mapping African biblical interpretation: A tentative sketch', in G.O. West \& M.W. Dube (eds.), The Bible in Africa: Transactions, trends and trajectories, pp. 29-53, Brill, Leiden.
West, G.O., 2000b, 'Contextual Bible study in South: A resource for reclaiming and regaining land, dignity and identity', in G.O. West \& M.W. Dube (eds.), The Bible in Africa: Transactions, trends, and trajectories, pp. 595-610, Brill, Leiden.

West, G.O., 2000c, 'Indigenous exegesis: Exploring the interface between missionary methods and the rhetorical rhythms of Africa - Locating local reading resources in the Academy', viewed 09 September 2012, from www.chora-strangers.com

West, G.O., 2004, 'Comparison and reception paradigms', in Y. Khiok-Khng (ed.) Navigating Romans through cultures: Challenging readings by charting a new course, pp. 83-90, Continuum, London.

Zimmermann R. \& Van der Watt, J.G., 2010, Moral language in the New Testament Mohr Siebeck, Tübingen.

Zuzan, M, 1983, “Une discussion sur les “oeuvres": Approche éxègetiques de Jn 6 , 26-30', Revue Africaine Théologie 7(4), 165-179. 